\title{
Essential Oils for Alternative Teak Rust Control
}

\author{
Pedro Raymundo Argüelles Osorio ${ }^{1}$, Evelynne Urzêdo Leão ${ }^{1}$, \\ Ronice Alves Veloso ${ }^{1}$, Dalmarcia de Souza Carlos Mourão ${ }^{1}$, \\ Gil Rodrigues dos Santos ${ }^{1}$
}

${ }^{1}$ Laboratório de Fitopatologia, Universidade Federal do Tocantins - UFT, Gurupi/TO, Brasil

\begin{abstract}
The objectives of this study were to evaluate the effect of lemon grass, citronella grass, Mexican-tea and noni essential oils on urediniospore germination of Olivea neotectonae, the agent responsible for rust in Teak (Tectona grandis L.f.); to evaluate the phytotoxic effect of these essential oils on teak seedlings; and to evaluate the use of essential oils to control rust in teak plants when preventively and curatively applied. We found that the noni and lemon grass essential oils inhibited $100 \%$ of urediniospore germination. On the other hand, the essential oils from noni and lemon grass caused phytotoxicity when applied to seedlings at concentrations of 2000 and $1500 \mu \mathrm{L} \mathrm{L}^{-1}$, respectively. The major constituents found in lemon grass essential oil were Geranial and Neral, while Octanoic Acid was found in noni oil. Lower values in the area below the rust progress curve were observed with the preventive application of lemon grass and noni essential oils.
\end{abstract}

Keywords: Olivea neotectonae, reforestation, forest pathology. 


\section{INTRODUCTION}

One of the main problems faced by Teak producers (Tectona grandis L. f.) are the diseases that affect the plants from the seedling stage up to the adult phase. Among the main diseases is teak rust caused by the Olivea neotectonae fungus (T.S. Ramakrishnan \& K. Ramakrishnan). The symptoms start on the leaf's under surface, causing chlorotic spots that progress rapidly into lesions which can lead to necrosis until generalized burning in the leaves occurs, consequently causing complete defoliation of the plant. Powdery uredinias with a yellow-orange color can be observed in the under part due to the intensive formation of urediniospores (Arguedas, 2004; Bonaldo et al., 2011).

Few studies focusing on the control of this disease are available. Firstly, the monitoring of seedling production in nurseries is recommended, eradicating those plants that present symptoms (Ferrari, 2011). There are no fungicides currently registered in Brazil to control this disease, however in practice it is common to observe the use of these products, mainly in nurseries. It is known that indiscriminate pesticide use has adversely affected the environment and human health due to soil, water, animal and food contamination. This fact has motivated research institutions to search for less polluting control alternatives. Of these methods, a demand for medicinal, spice and aromatic plants has increased due to the discovery of molecules with antimicrobial potential, such as terpenes, phenolic compounds and alkaloids. Several studies have demonstrated bioinseticidal, biofungicidal and bioherbicidal effects able to replace pesticides and reduce environmental impacts (Ootani et al., 2013; Isman et al., 2011). Studies involving the use of essential oils have shown inhibitory activity on other rust-causing fungi, such as coffee rust caused by Hemileia vastatrix Berk. \& Br. (Pereira et al., 2012), Asian soybean rust, in which the pathogen is Phakopsora pachrhizi Syd. \& P. Syd. (Medice et al., 2007), and grape rust caused by Phakopsora euvitis Y. Ono. (Fialho et al., 2015).

In addition to the importance of the disease, we should also consider that there are no studies in the current literature demonstrating the efficacy of essential oil use to control teak rust. Thus, the present study aims to evaluate the efficiency of applying essential oils in the preventive and curative control of Teak rust.

\section{MATERIAL AND METHODS}

\subsection{Production of teak seedlings}

Teak seeds arising from Caceres/MT were planted in plastic trays containing soil and commercial substrate at a proportion of 2:1. After germination, the seedlings were transferred to polystyrene bags containing $2 \mathrm{~kg}$ of substrate composed of a soil, manure and commercial substrate mixture at a ratio of 2:1:1. Irrigation was performed daily by hand with a watering can.

\subsection{Obtaining urediniospores}

The urediniospores were collected from infected teak leaves presenting rust symptoms from an experimental Teak planting area in a Cerrado area in the municipality of Gurupi-TO, Brazil. Next, the urediniospores were removed with the aid of a soft-bristle brush, lightly scraping the uredium present on the leaves. They were subsequently placed in $5 \mathrm{~mL}$ amber bottles and stored in a freezer at $-2{ }^{\circ} \mathrm{C}$ for a maximum period of one week until use.

\subsection{Collection of plant material and extraction of essential oils}

Lemon grass (Cymbopogon citratus (DC.) Stapf.), citronella grass (Cymbopogon nardus (L.) Rendle) and Mexican-tea (Chenopodium ambrosioides L.) leaves were collected in the municipality of Gurupi in the state of Tocantins, Brazil, and dehydrated in an oven for five days at a constant temperature of $40^{\circ} \mathrm{C}$ to avoid losses of volatile compounds sensitive to high temperatures. After dehydration, they were cut into small pieces for later use. Ripe noni fruits (Morinda citrifolia L.) were collected from the study region, submitted to asepsis and cut into small cubes for essential oil extraction. Two hundred grams (200 g) of each plant material lemon grass, citronella grass and Mexican-tea leaves and ripe noni fruits - were used for extraction. Extraction was performed using the hydrodistillation method in a Clevenger apparatus coupled to a refrigerated condenser, and boiled for a period of two hours. After extraction, the essential oils were collected as supernatant with the aid of a micropipette, placed in amber bottles and stored in a refrigerator at $4{ }^{\circ} \mathrm{C}$ until testing (Seixas et al., 2012, adapted). 


\subsection{Evaluation of essential oils in inhibiting the germination of urediniospores in vitro}

Small $10 \mathrm{~mL}$ vials were used to evaluate the effect of the oils on the O. neotectonae germination. Urediniospores collected from plant leaves with signs of the pathogen were used to prepare a concentrated solution of $1 \times 10^{6}$ urediniospores $\mathrm{mL}^{-1}$. Lemon grass, citronella grass, Mexican-tea and noni essential oils were tested at concentrations of $(250,500,750,1000$, $1250,1500,1750,2000$ and $\left.4000 \mu \mathrm{L} \mathrm{L}^{-1}\right)$ with four replicates. The experimental design was completely randomized in a factorial scheme (with four replicates, where the factors were four types of essential oil and nine concentrations for each essential oil). Control flasks contained only distilled water with the urediniospores in order to compare the results.

The essential oils were mixed in a solution of sterile distilled water+Tween 80 surfactant (1\%) for complete dissolution. $50 \mu \mathrm{L}$ of the essential oil solution was added to flasks at different concentrations, and then $50 \mu \mathrm{L}$ of urediniospore suspension at a concentration of $1 \times 10^{6} \mathrm{~mL}^{-1}$ was also added. The vials were stored in an incubation chamber at $25 \pm 2{ }^{\circ} \mathrm{C}$ in the dark for 48 hours.

After the incubation time, an evaluation was performed by counting germinated and non-germinated urediniospores, where a total of 400 urediniospores was counted for each treatment (100 per repetition) with the aid of a binocular microscope. Spores that presented a germ tube with a length greater than the evaluated urediniospore were considered germinated.

\subsection{Phytotoxicity test}

After the evaluation of the essential oils most effective at inhibiting in vitro urediniospore germination, a phytotoxicity test of lemon grass and noni essential oils in Teak plants was carried out using the same concentrations as described in the previous test. The experimental design was completely randomized in a factorial scheme, with three replications. The factors were two types of essential oils (noni and lemon grass) at nine concentrations.

A control with the application of only distilled water in the plants was used to compare the results. Different concentrations of the essential oils were separately mixed in sterile distilled water + Tween
80 surfactant (1\%) solution, and then stirred until homogenization. Manual spray bottles containing $30 \mathrm{~mL}$ of solution were used to apply the essential oils, with separate spray bottles for each oil type. The plants were sprayed late in the afternoon to prevent oil evaporation until they were soaked, and were kept in the laboratory after spraying for a period of 24 hours at $25 \pm 2{ }^{\circ} \mathrm{C}$. The phytotoxicity evaluation was carried out after 24 hours using the adapted scale of Dequech et al. (2008), Freitas et al. (2009) and Cogliatti et al. (2011), where: $0 \%=$ absence of phytotoxicity; $1-25 \%=$ slight necrosis in the leaves or mild chlorosis of the plant; $26-50 \%=$ moderate leaf necrosis or moderate chlorosis of the plant; $51-75 \%=$ severe leaf necrosis or severe chlorosis of the plant; $76-100 \%$ = wilt and dryness of the plant.

\subsection{Chromatographic analyses of lemon grass and noni essential oils}

Qualitative and quantitative analyses of the essential oils were performed by gas chromatography coupled with GC-MS mass spectrometry. The chromatograph used was a GC-210 Shimadzu equipped with a QP2010 Plus mass selector detector, and the apparatus was operated under the following conditions: RTX-5MS fused silica capillary column $(30 \mathrm{~m} \times 0.25 \mathrm{~mm} \times 0.25 \mu \mathrm{m}$ film thickness); with the following temperature programming in the column: $60-240{ }^{\circ} \mathrm{C}\left(3^{\circ} \mathrm{C} / \mathrm{min}\right)$; injector temperature: $220^{\circ} \mathrm{C}$; helium gas carrier; splitless injection with $1 \mu \mathrm{l}$ injected volume of a 1:1000 solution in hexane. For the mass spectrometer (MS), the following conditions were used: $70 \mathrm{eV}$ impact energy and $200^{\circ} \mathrm{C}$ temperature of the ion source and the interface. A homologous series of n-alkanes was injected under the same conditions as the samples $\left(\mathrm{C}_{9} \mathrm{H}_{20} \ldots \ldots . . \mathrm{C}_{26} \mathrm{H}_{54}\right)$. The spectra obtained were compared with the Nist and Wiley 229 database, and the retention index was calculated for each constituent, and then compared with the table according to Adams (2007).

Quantification of the compound contents was expressed as a percentage based on normalization of areas, which were obtained by a gas chromatograph equipped with a flame ionization detector (FID), using a Shimadzu GC-210 apparatus under the following conditions: RTX-5MS capillary column (30 $\mathrm{m} \times 0.25 \mathrm{~mm} \times 0.25 \mu \mathrm{m}$ film thickness); injector temperature: $220^{\circ} \mathrm{C}$; FID temperature: $300^{\circ} \mathrm{C}$; with 
column programming: initial temperature of $60^{\circ} \mathrm{C}$ with a heating rate of $3^{\circ} \mathrm{C} \mathrm{min}^{-1}$ up to $240^{\circ} \mathrm{C}$, subsequently undergoing a heating rate of $10{ }^{\circ} \mathrm{C} \mathrm{min}^{-1}$ up to 300 ${ }^{\circ} \mathrm{C}$, and remaining at that temperature for $10 \mathrm{~min}$; nitrogen entrainment gas $\left(1.18 \mathrm{~mL} \mathrm{~min}^{-1}\right)$; split ratio 1:50; pressure of $115 \mathrm{KPa}$ in the column and injected volume of $1 \mu \mathrm{L}$ of a 1:1000 solution in hexane.

\subsection{Preventive and curative in vivo teak rust control}

Based on the results obtained in the in vitro and phytotoxicity tests, preventive and curative control tests for Teak rust were set up in which noni and lemon grass essential oils were used. The concentrations used were $(250,500,750,1000,1250,1500,1750$, 2000 and $\left.4000 \mu \mathrm{L} \mathrm{L}^{-1}\right)$ for noni oil; and (250, 500, 750, $1000,1250,1500$ and $1750 \mu \mathrm{L} \mathrm{L}^{-1}$ ) for lemon grass oil; and only distilled water in the control. A completely randomized design was used in a factorial scheme with three replicates.

These solutions were prepared as previously described in the phytotoxicity test. The spore solution $(500 \mathrm{~mL})$ was prepared with sterile distilled water and $5 \mathrm{mg}$ of urediniospores, stirred, and then the urediniospores were quantified in a Neubauer chamber, adjusting to a concentration of $1 \times 10^{6}$ urediniospores $\mathrm{mL}^{-1}$.

Three completely healthy teak plants with five leaves each were used for preventive control tests, in which noni and lemon grass essential oil solutions were previously applied in their respective concentrations using hand sprays $(500 \mathrm{~mL})$ until they were soaked. After 24 hours, $10 \mathrm{~mL}$ of urediniospores per plant were inoculated by hand spraying $(500 \mathrm{~mL})$. After application of the urediniospore solution, the seedlings were placed in a humid chamber for 48 hours to provide adequate conditions for pathogen development.

Five disease severity evaluations at four-day intervals were performed starting two days after inoculation, adopting the severity score adapted from Santos et al. (2005): 0 = healthy plant; $1=$ less than $1 \%$ of diseased leaf area; $3=1$ to $5 \%$ of diseased leaf area; $5=6$ to $25 \%$ of diseased leaf area; $7=26$ to $50 \%$ of diseased leaf area; $9=$ more than $50 \%$ of diseased leaf area.

For the curative effect test, essential oils were applied on leaves presenting disease symptoms equivalent to Grade 1 on the severity scale, with less than $1 \%$ of diseased leaf area. The noni and lemon grass essential oil solutions were subsequently applied at the respective concentrations described above, using a manual sprayer (500 mL) until the plants were soaked. Application was done in the afternoon to avoid essential oil evaporation, and a control with only distilled water was also performed. Five disease severity evaluations at four-day intervals were conducted starting four days after applying the essential oils, using the previously described severity scale.

\subsection{Statistical analyses}

The results obtained in the in vitro germination inhibition test and from preventive and curative in vivo control were submitted to regression using the Sigma Plot v.10.0 computer program.

\section{RESULTS AND DISCUSSION}

\subsection{Evaluation of essential oils in the inhibition of in vitro urediniospore germination}

Regarding the germination of O. neotectonae urediniospores, there are no reports in the literature as to the inhibitory effect provided by essential oils. We found that the noni, Mexican-tea, lemon grass and citronella grass essential oils reduced urediniospore germination as essential oil concentrations increased (Figure 1).

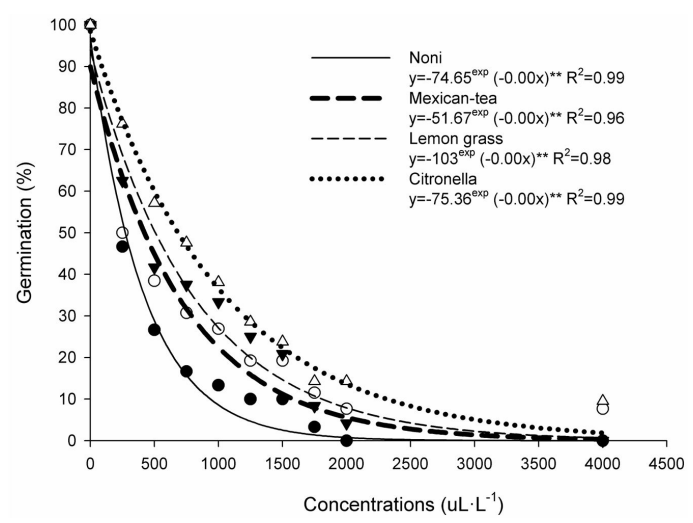

Figure 1. Urediniospores germination percentage of Olivea neotectonae subjected to different concentrations $(250,500,750,1000,1250,1500,1750,2000$ and 4000 $\mathrm{uL} \mathrm{L}{ }^{-1}$ ) of noni (Morinda citrifolia L.), Mexican-tea (Chenopodium ambrosioides L.), lemon grass (Cymbopogom citratus (DC.) Stapf) and citronella (Cymbopogom nardus (L.) Rendle) essential oils. ${ }^{*}$ Significant by $\mathrm{F}$ test at $1 \%$ probability. 
The noni fruit essential oil at a concentration of $2000 \mu \mathrm{L} \mathrm{L}^{-1}$ inhibited urediniospore germination by $100 \%$. There is a lack of information regarding the biological activity of noni fruit essential oil in phytopathogenic fungi. However, Sahoo et al. (2012) reported the fungitoxic potential of noni leaf extract on different fungal species considered important phytopathogens among different cultures. The main use for noni plants (leaves, roots, fruit, stems and bark) is as food and juice, being recommended to treat several human diseases (McClatchey, 2002; Wang et al., 2002; Palu et al., 2008).

Lemon grass essential oil at the highest tested concentration $\left(4000 \mu \mathrm{L} \mathrm{L}^{-1}\right)$ completely inhibited urediniospore germination. Some studies have found that lemon grass essential oil has insecticidal (Soares et al., 2011) and antifungal properties (Tzortzakis \& Economakis 2007). Guimarães et al. (2011) confirmed that lemon grass essential oil and its citral component (geranial + neral) have fungitoxic activity on several phytopathogens, corroborating the results obtained in this study.

Increasing concentrations of Mexican-tea and citronella grass essential oils decreased urediniospore germination, representing a germination percentage of 7.69 and $9.52 \%$ at the highest concentration, respectively. This means Mexican-tea and citronella grass essential oils, despite providing reduced urediniospore germination, were not completely efficient in in vitro control when compared to noni and lemon grass essential oils. However, promising results were observed in other parasite-systems with the use of citronella grass and Mexican-tea essential oils. Pereira et al. (2012), in analyzing the in vitro effect of essential oils on the urediniospore germination of Hemileia vastatrix (Berk. \& Br.) found germination inhibition for citronella grass essential oils. Jaramillo et al. (2012) reported an inhibitory effect on the mycelial growth of Fusarium oxysporum f. sp. from the leaves and stems of Mexican-tea essential oil.

\subsection{Phytotoxic effect of noni and lemon grass essential oils on Teak plants}

Noni essential oil caused phytotoxicity in Teak plants from the concentration $2000 \mu \mathrm{L} \mathrm{L}^{-1}$; however, it showed low toxicity $(\leq 25 \%)$ for the tested plants. Lemon grass essential oil caused phytotoxicity $(\leq 25 \%)$ starting at the concentration of $1500 \mu \mathrm{L} \mathrm{L}^{-1}$, with concentrations above $2000 \mu \mathrm{L} \mathrm{L}^{-1}$ causing increased phytotoxic symptoms (necrosis or chlorosis) (Figure 2). The main phytotoxicity symptom in Teak plants was the appearance of leaf necrosis, especially in leaf veins. Considering the results obtained, a significant difference between noni and lemon grass essential oils was observed.

Necrosis due to the phytotoxic action of the essential oil reduces leaf area, thereby interfering in the photosynthetic process, and consequently preventing photoassimilate production. There are few studies in the literature that discuss the phytotoxic effect of essential oils on forest species, principally Teak. However, several studies have already been developed in other crops, olive groves and annual plants. In evaluating the phytotoxicity of lemon grass essential oil in watermelon [Citrullus lanatus (Thunb.) Matsum. \& Nakai], beans (Phaseolus vulgaris L.) and rice (Oryza sativa L.) plants, Sarmento-Brum et al. (2014) found that $0.5 \%$ concentration was not phytotoxic for the seedlings of these crops.

Even in the case of deciduous forest species, phytotoxicity testing is very important in studies on the potential for essential oil use in nurseries for alternative disease control. In most studies, the promising results presented by in vitro tests were not always maintained in the in vivo tests, mainly due to the damage that the oils cause to the plant. In this case, phytotoxicity tests

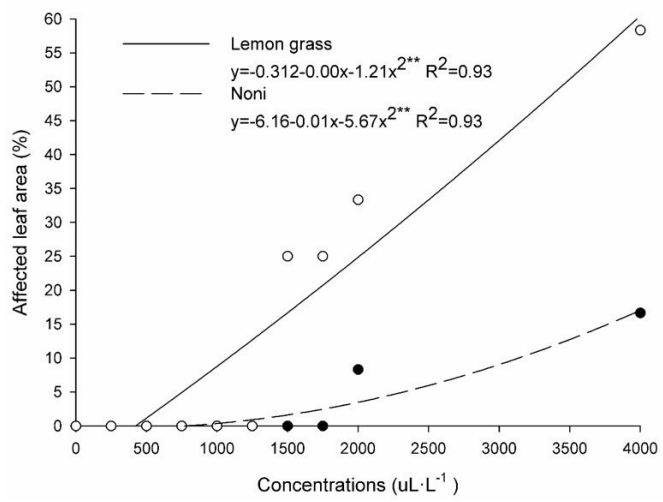

Figure 2. Percentage of leaf area in teak plants affected by phytotoxicity of different $(250,500,750,1000$, 1250, 1500, 1750, 2000 and $4000 \mathrm{uL} \mathrm{L}^{-1}$ ) lemongrass (Cymbopogom citratus (DC.) Stapf) and noni (Morinda citrifolia L.) essential oils concentrations. ${ }^{\star *}$ Significant by $\mathrm{F}$ test at $1 \%$ probability. 
served as a basis to determine the concentrations that can be applied to plants without harming them.

\subsection{Chromatographic analyses of essential oils}

It can be observed (Table 1) that the major chemical constituents present in the essential oil from lemon grass leaves were Geranial (41.46\%), and Neral (32.43\%), while in the essential oil extracted from ripe noni fruits, it was octanoic acid with $64.03 \%$ (Table 1 ).

High geranial and neral levels were found in the chemical composition of lemon grass by Pinto et al. (2014), with an average of approximately $51 \%$ and $36 \%$, respectively. Lacerda et al. (2014) also found octanoic acid as a major constituent in noni essential oil, with

Table 1. Chemical constituents of lemongrass (Cymbopogon citratus (DC.) Stapf) and noni(Morinda citrifolia L.) essential oils identified by GC / MS and their content expressed as a percentage. Gurupi-TO, 2016.

\begin{tabular}{|lccc|}
\multicolumn{4}{c}{ Lemon grass essential oil } \\
\hline \multicolumn{1}{c}{ Constituents } & RT & IR & $(\%)$ \\
\hline Myrcene & 7.742 & 986 & 9.73 \\
\hline (Z)- -ocimene & 9.344 & 1020 & 0.32 \\
\hline (E)- $\beta$-ocimene & 9.753 & 1029 & 0.16 \\
\hline Linalool & 11.845 & 1074 & 1.64 \\
\hline Neral & 17.885 & 1209 & 32.43 \\
\hline Geraniol & 18.375 & 1220 & 4.52 \\
\hline Geranial & 19.233 & 1239 & 41.46 \\
\hline Undecan-2-one & 20.099 & 1359 & 0.35 \\
\hline Geranyl acetate & 23.737 & 1443 & 0.42 \\
\hline E)-Caryophyllene & 31.997 & 1641 & 0.17 \\
\hline Others & - & - & 8.8 \\
\hline Total & & & 100 \\
\hline \multicolumn{1}{c}{ Noni essential oil } & & & \\
\hline 2-heptanone & 5.013 & 927 & 0.14 \\
\hline Hexanoate methyl & 5.787 & 944 & 1.08 \\
\hline Etil-hexanoato & 7.996 & 991 & 0.5 \\
\hline Hexanoic acid & 8.688 & 1006 & 8.64 \\
\hline Butanoic, 4-pentenyl ester & 10.395 & 1043 & 0.19 \\
\hline Octamoate metil & 12.755 & 1094 & 5.35 \\
\hline Octanoate acetate & 15.846 & 1163 & 3.58 \\
\hline Octanoic acid & 17.413 & 1198 & 64.03 \\
\hline 4-Pentnyl Hexanoate & 18.602 & 1225 & 4.3 \\
\hline Decanoic acid, methyl ester & 21.39 & 1288 & 0.19 \\
\hline Butanoic acid, 3-methyl & 26.995 & 1420 & 10.16 \\
\hline Hexyl Caprylate & 31.939 & 1540 & 0.37 \\
\hline Others & - & - & 1.47 \\
\hline Total & & & 100 \\
\hline RT- & & \\
\hline
\end{tabular}

$\mathrm{RT}=$ retention time; $\mathrm{IR}=$ calculated retention index .
78.81\%. A total of 160 phytochemical compounds have already been identified in noni fruit extracts, in which most of the constituents are phenolic compounds, organic acids and alkaloids (Chan-Blanco et al., 2006). Guimarães et al. (2011) found that the Geranial and Neral constituents have a fungicidal effect in the control of Alternaria alternata (Fr. Fr.) Keissl. These same compounds have been reported as having an antifungal potential (Lee et al., 2008). On the other hand, no studies in the current literature on the use of the Octanoic Acid compound of noni essential oil were found for phytopathogen control.

Through a preliminary chemical analysis of the essential oils of some plants, it was possible to identify several compounds of agronomic interest present in the oils. The majority constituents of geranial and neral in lemon grass oil and the octanoic acid in noni oil may be indicative of these substances being responsible for the control of Teak rust effect. Future studies should focus on the isolated effect of these compounds on disease control.

\subsection{Preventive and curative control of Teak rust}

The use of lemon grass essential oil was very efficient when applied on plants as a preventive treatment, presenting low area under the disease-progress curve (AUDPC) values above the concentration of $250 \mu \mathrm{L} \mathrm{L}^{-1}$, where there was no development of any characteristic disease symptoms. A good level of control was also found when applied curatively; however, it was possible to observe the development of lesions even when the largest tested dose was used (Figure 3A).

Regarding noni essential oil, and similar to that found for the effect of lemon grass, a greater efficiency of the preventive control was also verified in comparison to the curative effect (Figure 3B). However, lemon grass was more effective when compared to noni, mainly in the curative control. The latter was only completely efficient for controlling the disease after a concentration of $4000 \mu \mathrm{L} \mathrm{L}^{-1}$ (Figure 3B).

The oil was applied for preventive control prior to infection occurring in plant tissues. Therefore, a barrier was probably created to prevent pathogen germination and penetration of the germ line on the leaf surface. Regarding the difference observed between lemon grass 

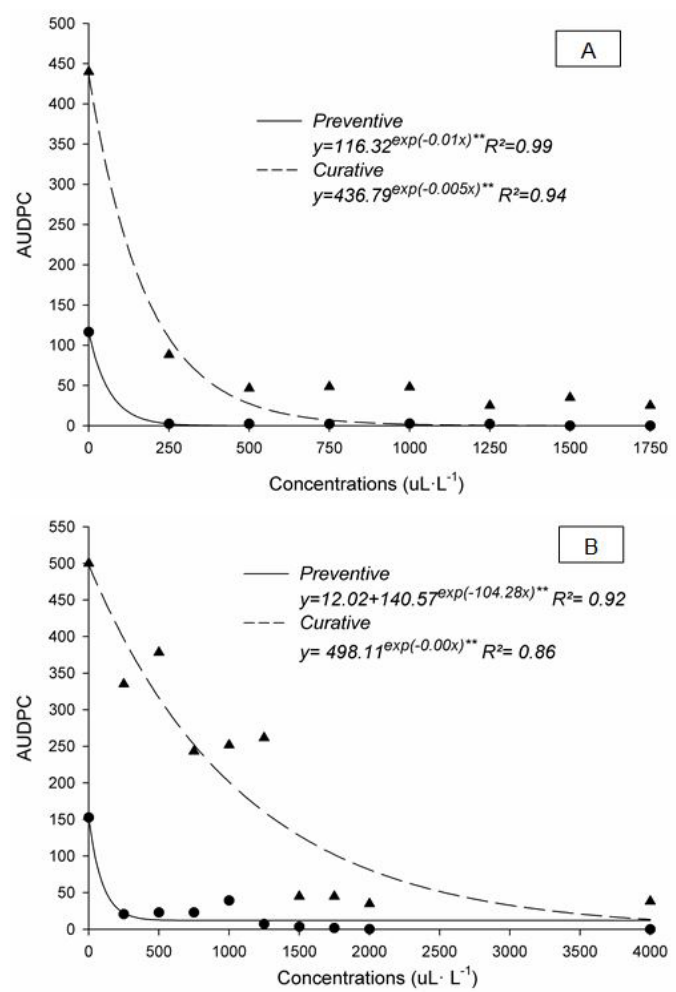

Figure 3. Area under the rust progress curve (AUDPC) of teak at different lemongrass (Cymbopogon citratus (DC.) Stapf.) (A) and noni (Morinda citrifolia L.) (B) essential oil concentrations. ${ }^{* *}$ significant by $\mathrm{F}$ test at $1 \%$ probability.

and noni essential oils in terms of control efficiency, this could be attributed to the fact that the major constituent of noni (octanoic acid) is highly volatile in contact with the open air, and therefore probably presented a low residual effect due to this characteristic.

Results similar to the ones obtained in this study have shown the efficiency of essential oils in controlling diseases in other pipatosystems. Medice et al. (2007) found that the essential oils of citrus eucalyptus (Corymbia citriodora Hill \& Johnson), citronella grass (Cymbopogon nardus (L.) Rendle.), nimtree (Azadirachta indica A. Juss.) and thyme (Thymus vulgaris L.) delay the development of Asian soybean rust (P. pachyrhizi Syd. \& P. Syd) in the greenhouse. In evaluating cinnamon (Cinnamomum zeylanicum Blume.), citronella grass (Cymbopogon nardus (L.) Rendle.), lemon grass (Cymbopogon citratus (DC.) Stapf.), clove (Syzygium aromaticum (L.) Merr. \& L. M. Perry), tea-tree (Melaleuca alternifolia Cheel.), thyme
(Thymus vulgris L.), nimtree (Azadirachta indica A. Juss.) and eucalyptus (Corymbia citridora Hill \& Johnson) essential oils for coffee rust ( $H$. vastatrix Berk. \& Br.) control, Pereira et al. (2012) found that all the oils promoted partial disease control.

The partial control of Teak rust obtained in this study by applying the essential oils is possibly due to the presence of toxic compounds in large quantities in the essential oils used, which have the capacity to induce a protective effect. On the other hand, other compounds in smaller amounts may indirectly contribute to controlling the disease, by inducing a defensive response in the plant. In order to confirm this hypothesis, it is necessary to conduct further research aiming to quantify the enzymes related to plant defense after applying these oils.

The results obtained demonstrate the possibility of controlling Teak rust caused by $O$. neotectonae with essential oils. We verified that noni and lemon grass essential oils have high viability potential in preventive and curative disease control. It is important that further research be developed seeking to test the efficiency of essential oils from other plants, and to verify which action mechanisms of the compounds that control the pathogen are present in the oils.

\section{CONCLUSIONS}

Lemon grass, citronella grass, Mexican-tea and noni essential oils had an inhibitory effect on $O$. neotectone urediniospore germination.

Phytotoxicity symptoms were observed in Teak leaves when applying lemon grass and noni essential oils.

The preventive application of lemon grass and noni essential oils was more effective to prevent teak rust when compared to the curative application.

\section{ACKNOWLEDGEMENTS}

The National Council of Science and Technology (CONACYT) of Mexico for providing financial support.

\section{SUBMISSION STATUS}

Received: 6 sept., 2016

Accepted: 26 july, 2017 


\section{CORRESPONDENCE TO}

\section{Gil Rodrigues dos Santos}

Laboratório de Fitopatologia, Universidade

Federal do Tocantins - UFT, Rua Badejós, Lote

7, Chácaras 69/72, Zona Rural, CEP 77402-970,

Gurupi, TO, Brasil

e-mail: gilrsan@mail.uft.edu.br

\section{FINANCIAL SUPPORT}

\section{CONACYT.}

\section{REFERENCES}

Adams RP. Identification of essential oil componentsby gas chromatography/mass spectrometry. 4th ed. Carol Stream: Allured Publishing Corporation; 2007.

Arguedas M. La roya de La teça Olivea tectonae (Rac.): consideraciones sobre su presencia em Panamá y Costa Rica. Revista Forestal Kuru 2004; 1(1): 1-16.

Bonaldo MS, Barceli CA, Trento AR, Gasparotto F, Taffarel C. Relato oficial da ocorrência de Olivea tectonea em teca (Tectona grandis) no Brasil. Summa Phytopathologica 2011; 37(3): 153. http://dx.doi.org/10.1590/S010054052011000300015 .

Chan-Blanco Y, Vaillant F, Mercedes Perez A, Reynes M, Brillouet J-M, Brat P. The noni fruit (Morinda citrifolia L.): a review of agricultural research, nutritional and therapeutic properties. Journal of Food Composition and Analysis 2006; 19(6-7): 645-654. http://dx.doi.org/10.1016/j. jfca.2005.10.001.

Cogliatti M, Juan VF, Bongiorno F, Dalla Valle H, Rogers WJ. Control of grassy weeds in annual canarygrass. Crop Protection 2011;30(2): 125-129. http://dx.doi.org/10.1016/j. cropro.2010.11.002.

Dequech BTS, Ribeiro PL, Sausen DC, Egewarth R, Kruse DN. Fitotoxicidade causada por inseticidas botânicos em feijão-de-vagem (Phaseolus vulgaris L.) cultivado em estufa plástica. Revista da FZVA 2008; 15(1): 71-80.

Ferrari JT. Ferrugem (Olivea tectonae) em plantas de teca. São Paulo: Instituto Biológico; 2011. 6 p. (Documento Técnico; no. 009).

Fialho RO, Papa MFS, Pereira DAS. Efeito fungitóxico de óleos essenciais sobre Phakopsora euvitis, agente causal da ferrugem da videira. Arquivos do Instituto Biológico 2015; 82: 1-7. http://dx.doi.org/10.1590/1808-1657000702013.

Freitas SP, Moreira JG, Freitas ILJ, Freitas SP Jr, Amaral AT Jr, Silva VQR. Fitotoxicidade de herbicidas a diferentes cultivares de milho pipoca. Planta Daninha 2009; 27(spe): 1095-1103. http://dx.doi.org/10.1590/S010083582009000500023.
Guimarães LGL, Cardoso GM, Sousa EP, Andrade J, Vieira SS. Atividades antioxidante e fungitóxica do óleo essencial de capim-limão e do citral. Revista Ciência Agronômica 2011; 42(2): 464-472. http://dx.doi.org/10.1590/S180666902011000200028 .

Isman MB, Miresmailli S, Machial C. Commercial opportunities for pesticides based on plant essential oils in agriculture, industry and consumer products. Phytochemistry Reviews 2011; 10(2): 197-204. http:// dx.doi.org/10.1007/s11101-010-9170-4.

Jaramillo CEB, Duarte RE, Delgado W. Bioactividad del aceite esencial de Chenopodium ambrosioides colombiano. Revista Cubana de Plantas Medicinales 2012; 17(1): 54-64.

Lacerda DA, Medeiros VM, Gome SRA, Matias WN. Investigação da atividade citotóxica do fruto da Morinda citrifolia Linn (noni). In: Anais do I Congresso Nacional de Ciências da Saúde; 2014; Cajazeiras, Paraíba. Cajazeiras: CONACIS; 2014.

Lee YS, Kim J, Shin SC, Lee SG, Park IK. Antifungal activity of Myrtaceae essential oils and their components against three phytopathogenic fungi. Flavour and Fragrance Journal 2008; 23(1): 23-28. http://dx.doi.org/10.1002/ffj.1850.

McClatchey W. From Polynesian healers to health food stores: changing perspectives of Morinda citrifolia (Rubiaceae). Integrative Cancer Therapies 2002; 1(2): 110-120. http://dx.doi.org/10.1177/1534735402001002 002. PMid:14664736.

Medice R, Alves E, Assis RT, Magno RG Jr, Lopes EAGL. Óleos essenciais no controle da ferrugem asiática da soja Phakopsora pachyrhizi Syd. e P. Syd. Ciência e Agrotecnologia 2007; 31(1): 83-90. http://dx.doi.org/10.1590/S141370542007000100013 .

Ootani MA, Aguiar RW, Ramos AC, Brito DR, Silva JBD, Cajazeira JP. Use of essential oils in agriculture. Journal of Biotechnology and Biodiversity 2013; 4(2): 162-175.

Palu AK, Kim A, West JB, Deng S, Jensen J, White L. The effects of Morinda citrifolia L. (noni) on the immune system: Its molecular mechanisms of action. Journal of Ethnopharmacology 2008; 115(3): 502-506. http://dx.doi. org/10.1016/j.jep.2007.10.023. PMid:18063495.

Pereira BR, Lucas CG, Perina JF, Alves E. Essential oils for rust control on coffee plants. Ciência e Agrotecnologia 2012; 36(1): 16-24. http://dx.doi.org/10.1590/S141370542012000100002 .

Pinto DA, Mantovani EC, Melo EDC, Sediyama GC, Vieira GHS. Produtividade e qualidade do óleo essencial de capim-limão, Cymbopogon citratus, DC. Submetido a diferentes lâminas de irrigação. Revista Brasileira de Plantas Medicinais 2014; 16(1): 54-61. http://dx.doi.org/10.1590/ S1516-05722014000100008.

Sahoo K, Dhal NK, Sahoo SL, Lenka SS. Comparative phytochemical and antimicrobial study of Morinda pubescens sm. and Morinda citrifolia L. International 
Journal of Pharmacy and Pharmaceutical Sciences 2012; 4(3): 425-429.

Santos GR, Café-Filho AC, Leão FF, César M, Fernandes LE. Progresso do crestamento gomoso e perdas na cultura de melancia. Horticultura Brasileira 2005; 23(2): 228-232. http://dx.doi.org/10.1590/S0102-05362005000200013.

Sarmento-Brum RBC, Castro GH, Gama RF, Cardon HC, Santos RG. Phytotoxicity of essential oils in watremelon, bean and rice plants. Journal of Biotechnology and Biodiversity 2014; 5(2): 101-109.

Seixas PTL, Castro HG, Cardoso DP, Chagas AF Jr, Nascimento IR. Bioactivity of essential oils on the fungus Didymella bryoniae of the cucumber culture. Brazilian Journal of Applied Technology for Agricultural Science 2012; 5(3): 61-66.
Soares ASC, Silva M, Costa BM, Bezerra SEC. Ação inseticida de óleos essenciais sobre a lagarta desfolhadora Thyrinteina arnobia (stoll) (Lepidoptera: Geometridae). Revista Verde de Agroecologia e Desenvolvimento Sustentável 2011; 6(2): 154-157.

Tzortzakis NG, Economakis CD. Antifungal activity of lemongrass (Cympopogon citratus L.) essential oil against key postharvest pathogens. Innovative Food Science of Emerging Technologies 2007; 8(2): 253-258. http://dx.doi. org/10.1016/j.ifset.2007.01.002.

Wang MY, West B, Jensen CJ, Nowicki D, Su C, Palu AK et al. Morinda citrifolia (Noni): a literature review and recent advances in Noni research. Acta Pharmacologica Sinica 2002; 23(12): 1127-1141. PMid:12466051. 